\title{
PROGRESSIVE INHIBITION OF UTERINE SENSITIVITY IN RATS FITTED WITH INTRA-UTERINE SUTURES
}

\author{
J. G. WOOD AND D. R. S. KIRBY* \\ Department of Zoology, University of Oxford \\ (Received 22nd Fuly 1969)
}

\begin{abstract}
Summary. The presence of a thread in a limited region of the rat uterus causes a gain in weight throughout the length of the uterine horn which bears it. In addition, such a thread lessens, but does not inhibit completely, the decidual cell response which can be induced by uterine trauma. This inhibition increases progressively with the length of time that the device has been present. A mechanism is suggested to explain this effect.
\end{abstract}

\section{INTRODUCTION}

The contraceptive action exerted by a silk suture placed within the rodent uterus has been the subject of a large number of studies since the effect was described by Doyle \& Margolis in 1963. At the present time, it is still not clear how such a contraceptive action is brought about, although it seems likely that the presence of a thread induces an intra-uterine environment which is unfavourable to the survival of the fertilized egg, and that it also prevents the differentiation of normal decidual cells.

Although this anti-decidual effect has been widely discussed and several suggestions have been put forward to account for it, few studies have investigated the extent to which the inhibition is operative or the time taken for it to become effective. It has been generally assumed that total inhibition of the decidual cell reaction occurs as soon as the thread is inserted. However, studies of our own (Wood \& Kirby, 1968, and unpublished) have revealed the fact that a decidual cell reaction can occasionally be induced in uteri bearing contraceptive sutures even though the threads may have been present for several months. This decidual cell response is quite distinct from a gain in uterine weight which follows the insertion of an intra-uterine thread, an effect which has been observed by a number of authors (see Parr, 1969).

The present work reports on a more comprehensive investigation of this problem and shows that although a small suture can exert a completely contraceptive action, it does not necessarily cause a total inhibition of the decidual cell response.

\section{MATERIALS AND METHODS}

All the rats in the study were sexually mature, virgin Wistar females obtained from Animal Suppliers (London) Ltd (London, N.12). They were matched

* David Kirby died on 11 th November 1969; a memoir appeared in this Journal Vol. 21, p. 379. 
as closely as possible for age and weight. All groups of animals, except one, underwent bilateral, subtotal tubectomy under Avertin anaesthesia (Bayer Products, Surbiton) and the majority also received a thread of $5 / 0$ surgical silk (Abrasilk, Armour Pharmaceutical Co., Eastbourne), which was inserted for a length of about $5 \mathrm{~mm}$ into the cervical region of the left uterine horn. After ensuring that the thread lay free inside the uterine lumen, it was again brought through the uterine wall and its two ends were tied and allowed to lie within the abdominal cavity. All animals were paired with males of proven fertility and the day upon which spermatozoa were recovered from the vaginal smear was designated as Day 0 of pregnancy or pseudopregnancy depending on whether or not tubectomy had been performed. In those animals in which an attempt was made to induce a decidual cell reaction, a burred hypodermic needle was passed down the inside of each uterine horn from the tubal to the cervical end and then made to scratch the whole anti-mesometrial length of the horn as it was withdrawn. This operation was always performed at the period of maximum uterine sensitivity (that is on the 4th day of pseudopregnancy), and it was always performed both on the horn bearing the thread and on the contralateral control horn in order to establish that the animal was truly pseudopregnant.

All rats were killed on Day 9. Their uteri were examined macroscopically for evidence of decidual cell response, then removed from the body, weighed and fixed for histology.

Animals were divided into seven groups as follows:

Group 1 (eight rats). Device inserted during pro-oestrus, animals mated normally the same night.

Group 2 (5-day control group; eight rats). Device inserted in pro-oestrus and tubectomy performed. No uterine trauma.

Group 3 (eight rats). As Group 2, but each uterine horn was accurately bisected transversely before weighing. The two halves of each horn were then weighed independently.

Group 4 (5-day experimental group; twelve rats). As Group 2, but uterine trauma carried out on Day 4.

Group 5 (15-day experimental group; ten rats). Device inserted in rats tubectomized. Rats rested for approximately 15 days then mated and uterine trauma carried out as for Group 4.

Group 6 (60-day control group; six rats). Device inserted and tubectomy performed. Rats killed after 60 days. No uterine trauma.

Group 7 (60-day experimental group; ten rats). As Group 6, but animals mated and uterine trauma carried out as for Group 4.

\section{RESULTS}

The results obtained in those animals mated on the night the device was inserted are summarized in Tables 1 and 2. It is clear that in Group 1 in which the device had been in place for approximately 5 days before the normal time of egg implantation, the thread was completely effective in preventing pregnancy in the horn which bore it. This result confirms the earlier findings of 
Psychoyos \& Bitton (1965). The mean weights of the intact horns bearing devices in Groups 1 and 2 did not differ significantly from each other but they were both significantly heavier $(P<0.001)$ than the intact control horn bearing no device in Group 2.

Table 2 shows the weights of the upper and lower portions of the control and device horns for the eight rats in Group 3 together with the significance of the difference between them. Both the upper and lower portions of the device

TABLE 1

WEIGHTS OF UTERINE HORNS AND NUMBER OF IMPLANTATION SITES IN PREGNANT AND PSEUDOPREGNANT RATS BEARING UNILATERAL INTRAUTERINE THREADS (GROUPS 1 AND 2)

\begin{tabular}{l|cc|cc}
\hline & \multicolumn{2}{|c|}{ Group 1 } & \multicolumn{2}{c}{ Group 2 } \\
\cline { 2 - 5 } & Control & Device & Control & Device \\
\hline $\begin{array}{l}\text { Mean wt of uterine } \\
\text { horn (mg } \pm \text { S.E.) }\end{array}$ & $479 \pm 85$ & $201 \pm 14$ & $135 \pm 7$ & $227 \pm 19$ \\
$\begin{array}{l}\text { Percentage of rats with } \\
\text { implantation sites }\end{array}$ & 100 & 0 & & \\
$\begin{array}{l}\text { Mean no. of } \\
\text { implantation sites per } \\
\text { horn }\end{array}$ & 6.0 & 0 & \multicolumn{2}{|c}{} \\
$\begin{array}{l}\text { No. of rats in each } \\
\text { group }\end{array}$ & & 8 & & \multicolumn{2}{|c|}{8} \\
\hline
\end{tabular}

TABLE 2

THE DISTRIBUTION OF UTERINE WEIGHT IN PSEUDOPREGNANT RATS BEARING UNILATERAL INTRA-UTERINE SUTURES* (GROUP 3)

\begin{tabular}{l|cc|cc}
\hline \multirow{2}{*}{} & \multicolumn{2}{|c|}{ Upper uterus } & \multicolumn{2}{|c}{ Lower uterus } \\
\cline { 2 - 4 } & Control Device & Control $\quad$ Device \\
\hline Weight $(\mathrm{mg} \pm$ S.E.) & $72 \pm 5 \quad 100 \pm 8$ & $56 \pm 5 \quad 122 \pm 12$ \\
Significance of difference & \multicolumn{2}{|c|}{$0.01<P<0.02$} & \multicolumn{2}{|c}{$0.001<P<0.01$} \\
No. of rats in each group & \multicolumn{2}{|c|}{8} & \multicolumn{2}{|c}{} \\
\hline
\end{tabular}

* Devices inserted in pro-oestrus. Tubectomy performed and rats mated the same night, then killed on Day 9.

side were heavier than their respective controls. However, the weights of the two halves of each horn did not differ significantly from each other, showing that the weight gain in the device side was evenly distributed along the length of the uterus.

In Group 4 (Table 3), all of the control horns subjected to trauma showed the presence of massive decidua. In the device side also, ten out of the twelve treated horns responded by undergoing some degree of decidual cell reaction which was quite distinct and readily distinguishable from the gain in weight already mentioned. The weight of the device-bearing horns subjected to trauma 
in Group 4 was significantly greater than that of the intact device-bearing horns in Groups 1 and $2(P<0.02)$. Indeed, the weight of decidual tissue present in the device side in Group 4 (calculated by subtracting the mean weight of the treated horn from that of the device-bearing, intact horns in Groups 1 and 2) was $340 \mathrm{mg}$, a value very similar to the weight of decidual tissue ( $344 \mathrm{mg}$ ) found in normal pregnant uteri (Group 1) bearing a mean of 6.0 implantations. The weight of decidual tissue was, however, much less than the $1097 \mathrm{mg}$ produced in response to trauma by horns carrying no intra-uterine threads.

Table 3 also summarizes the results obtained when the thread was left in place for varying periods of time. The mean body weight of rats in Group 6 $(232 \mathrm{~g})$ was significantly greater than the mean weight of those in Groups 1 and

TABLE 3

EFFEGT ON UTERINE WEIGHT OF A UNILATERAL INTRAUTERINE THREAD PRESENT FOR VARYING PERIODS OF TIME

\begin{tabular}{|c|c|c|c|c|}
\hline \multirow{3}{*}{$\begin{array}{c}\text { Time } \\
(\text { days })\end{array}$} & \multicolumn{4}{|c|}{ Mean wt of uterine horn $(m g \pm S . E)}$. \\
\hline & \multicolumn{2}{|c|}{ No trauma } & \multicolumn{2}{|c|}{ Trauma } \\
\hline & Control & Device & Control & Device \\
\hline 5 & $\begin{array}{l}135 \pm 7 \\
\text { Group } 2\end{array}$ & $\begin{array}{l}214 \pm 11 \\
\text { Group } 1 \\
\text { and } 2\end{array}$ & $\begin{array}{l}1232 \pm 84 \\
(12 / 12)^{*} \\
\text { Group } 4\end{array}$ & $\begin{array}{l}554 \pm 115 \\
(10 / 12) \\
\text { Group } 4\end{array}$ \\
\hline 15 & & & $\begin{array}{l}1316 \pm 98 \\
(10 / 10) \\
\text { Group } 5\end{array}$ & $\begin{array}{l}482 \pm 118 \\
(5 / 10) \\
\text { Group } 5\end{array}$ \\
\hline 60 & $\begin{array}{l}164 \pm 8 \\
\text { Group } 6\end{array}$ & $\begin{array}{l}345 \pm 17 \\
\text { Group } 6\end{array}$ & $\begin{array}{l}1465 \pm 149 \\
(10 / 10) \\
\text { Group } 7\end{array}$ & $\begin{array}{l}440 \pm 72 \\
(5 / 10) \\
\text { Group } 7\end{array}$ \\
\hline
\end{tabular}

* Figures in parentheses indicate the number of uterine horns showing a decidual cell reaction.

2 (196 g; $P<0.001)$. This may perhaps account for the increase in weight $(21 \%)$ of the intact control horn bearing no device in the 60-day compared with the 5-day group. However, the horn bearing the intra-uterine thread was also heavier than that on the contralateral control side after 60 days $(P<0 \cdot 001)$. In addition, the increase in weight in the device side compared to the control depends upon the length of time for which the device has been indwelling. It rose from $58 \%$ after 5 days to $110 \%$ after 60 days.

In response to trauma in the control side, a massive decidual cell reaction occurred irrespective of the length of time that the device had been present in the opposite horn. By contrast, the response to trauma of the device side did depend on the length of time that the thread had been present. After 5 days, ten out of twelve horns responded, and the difference in weight between the treated uteri and the lighter intact uteri bearing threads was significant $(P<0.02)$. After 15 days, five out of ten device-bearing uteri subjected to trauma also showed evidence of decidual cell response and the mean weight was again significantly greater than in the intact control group $(P=0.05)$. Even after 60 
days, five out of ten uteri produced some macroscopic and microscopic evidence of decidual cell response although by that time, the weight of the device horn had increased so markedly that the mean weights of treated and intact horns carrying devices did not differ significantly from each other.

\section{DISCUSSION}

The results show that a uterine horn bearing an intra-uterine thread can be induced to undergo a decidual cell reaction in response to trauma although its ability to do so declines progressively with the length of time that the thread has been indwelling. With the progressive decrease in the amount of decidual tissue produced, there is a corresponding increase in the weight of the intact device-bearing horns. This increase in weight is distributed evenly along the length of the uterine horn and is not restricted to the region around the thread. Histological examination of these device-bearing uteri shows the endometrium to have a dense compact appearance in contrast to the usual loose framework seen in the control side. This appearance is caused by an increase in the proportion of extracellular material. The metamorphosis of the stromal fibroblasts into larger and fully differentiated decidual cells probably involves a partial dissolution of the connective tissue matrix surrounding these cells (Wood \& Psychoyos, 1967). It seems reasonable to assume that in a situation in which the matrix is particularly dense and unyielding, decidual cell formation would be impaired in a progressive manner, corresponding with the increase in the accumulation of non-cellular material. It is, therefore, suggested that the progressive inhibition of uterine sensitivity brought about by the continued presence of an intra-uterine thread is due, at least in part, to a progressive accumulation of non-cellular material which interferes with decidual cell formation.

\section{ACKNOWLEDGMENTS}

This work was supported by a grant from the Medical Research Council, London, England.

\section{REFERENCES}

Doyle, L. L. \& Margolis, A. J. (1963) Intrauterine foreign body-effect on pregnancy in the rat. Science, N.Y. 139, 833.

PARR, E. (1969) The role of inflammation in the uterine weight increase caused by an IUD. F. Reprod. Fert. 18, 221.

Psychoyos, A. \& Bitron, V. (1965) Aspects chronologiques de l'effet anti-implantoire de la présence d'un fil dans l'utérus de la ratte. C. r. Séanc. Soc. Biol. 160, 229.

Wood, J. C. \& KIRBY, D. R. S. (1968) The effect of uterine anastomosis on the action of the IUCD in rats. Am. 7. Obstet. Gynec. 102, 1041.

Wood, J. C. \& Psychoyos, A. (1967) Activité de certains enzymes hydrolytiques dans l'endomètre et le myomètre au cours de la pseudogestation et de divers états de receptivité utérine chez la ratte. C. r. hebd. Séanc. Acad. Sci., Paris, 265, 141. 